\title{
Front Matter: Volume 6681
}

, "Front Matter: Volume 6681," Proc. SPIE 6681, Lidar Remote Sensing for Environmental Monitoring VIII, 668101 (22 October 2007); doi:

$10.1117 / 12.779345$

SPIE Event: Optical Engineering + Applications, 2007, San Diego, California, United SPIE. States 


\section{PROCEEDINGS OF SPIE}

\section{Lidar Remote Sensing for Environmental Monitoring VIII}

Upendra N. Singh

Editor

29-30 August 2007

San Diego, California, USA

Sponsored and Published by

SPIE

Volume 6681 
The papers included in this volume were part of the technical conference cited on the cover and title page. Papers were selected and subject to review by the editors and conference program committee. Some conference presentations may not be available for publication. The papers published in these proceedings reflect the work and thoughts of the authors and are published herein as submitted. The publisher is not responsible for the validity of the information or for any outcomes resulting from reliance thereon.

Please use the following format to cite material from this book:

Author(s), "Title of Paper," in Lidar Remote Sensing for Environmental Monitoring VIII, edited by Upendra N. Singh, Proceedings of SPIE Vol. 6681 (SPIE, Bellingham, WA, 2007) Article CID Number.

ISSN 0277-786X

ISBN 9780819468291

Published by

SPIE

P.O. Box 10, Bellingham, Washington 98227-0010 USA

Telephone +1 3606763290 (Pacific Time) · Fax +1 3606471445

SPIE.org

Copyright (C 2007, Society of Photo-Optical Instrumentation Engineers

Copying of material in this book for internal or personal use, or for the internal or personal use of specific clients, beyond the fair use provisions granted by the U.S. Copyright Law is authorized by SPIE subject to payment of copying fees. The Transactional Reporting Service base fee for this volume is $\$ 18.00$ per article (or portion thereof), which should be paid directly to the Copyright Clearance Center (CCC), 222 Rosewood Drive, Danvers, MA 01923. Payment may also be made electronically through CCC Online at copyright.com. Other copying for republication, resale, advertising or promotion, or any form of systematic or multiple reproduction of any material in this book is prohibited except with permission in writing from the publisher. The CCC fee code is $0277-786 \mathrm{X} / 07 / \$ 18.00$.

Printed in the United States of America.

Publication of record for individual papers is online in the SPIE Digital Library.

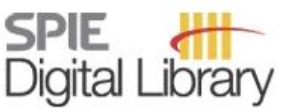

SPIEDigitallibrary.org

Paper Numbering: Proceedings of SPIE follow an e-First publication model, with papers published first online and then in print and on CD-ROM. Papers are published as they are submitted and meet publication criteria. A unique, consistent, permanent citation identifier (CID) number is assigned to each article at the time of the first publication. Utilization of CIDs allows articles to be fully citable as soon they are published online, and connects the same identifier to all online, print, and electronic versions of the publication. SPIE uses a six-digit CID article numbering system in which:

- The first four digits correspond to the SPIE volume number.

- The last two digits indicate publication order within the volume using a Base 36 numbering system employing both numerals and letters. These two-number sets start with 00, 01, 02, 03, 04, 05, $06,07,08,09,0 A, 0 B \ldots .0 Z$, followed by $10-1 Z, 20-2 Z$, etc.

The CID number appears on each page of the manuscript. The complete citation is used on the first page, and an abbreviated version on subsequent pages. Numbers in the index correspond to the last two digits of the six-digit CID number. 


\section{Contents}

vii Conference Committee

\section{AEROSOL AND CLOUD MEASUREMENTS I}

668102 Eye-safe aerosol lidar at 1.5 microns: progress toward a scanning lidar network (Invited Paper) [6681-01]

S. M. Spuler, S. D. Mayor, National Ctr. for Atmospheric Research (USA)

668103 Ultraviolet high-spectral resolution lidar with polarization detection for accurate measurement of optical properties of aerosol and clouds [6681-02]

H. Kawai, Y. Iwasaki, M. Imaki, T. Kobayashi, Univ. of Fukui (Japan)

668105 Lidar/photometry studies at São Paulo in the 2003-2005 period, Brazil [6681-05] E. Landulfo, P. Sawamura, S. T. Uehara, W. M. Nakaema, A. S. Torres, F. J. S. Lopes, C. A. Matos, W. C. de Jesus, Instituto de Pesquisas Energéticas e Nucleares (Brazil)

WIND LIDAR I

668106 Requirements and technology advances for global wind measurement with a coherent lidar: a shrinking gap (Invited Paper) [6681-06]

M. J. Kavaya, J. YU, G. J. Koch, F. Amzajerdian, U. N. Singh, NASA Langley Research Ctr. (USA); G. D. Emmitt, Simpson Weather Associates (USA)

668107 Development and testing of a risk reduction high energy laser transmitter for high spectral resolution lidar and Doppler winds lidar [6681-07]

J. Wang, Raytheon Santa Barbara Remote Sensing (USA); V. Leyva, Raytheon Space and Airborne Systems (USA); F. E. Hovis, Fibertek, Inc. (USA)

668109 Parameter trade studies for coherent lidar measurements of wind from space [6681-09] M. J. Kavaya, NASA Langley Research Ctr. (USA); R. G. Frehlich, Univ. of Colorado, Boulder (USA)

WIND LIDAR II

6681 OB Development of an airborne molecular direct detection Doppler lidar for tropospheric wind profiling [6681-11]

B. Gentry, M. MCGill, NASA Goddard Space Flight Ctr. (USA); G. Schwemmer, Science Engineering Services, Inc. (USA); M. Hardesty, A. Brewer, NOAA ESRL (USA); T. Wilkerson, Utah State Univ. Space Dynamics Lab. (USA); R. Atlas, NOAA AOML (USA); M. Sirota, Sigma Space Corp. (USA); S. Lindemann, Michigan Aerospace Corp. (USA); F. Hovis, Fibertek Inc. (USA) 
6681 OC Daytime rapid detection of minerals and organics from 50 and $100 \mathrm{~m}$ distances using a remote Raman system (Invited Paper) [6681-15]

A. K. Misra, S. K. Sharma, P. G. Lucey, R. C. F. Lentz, C. H. Chio, Univ. of Hawaii (USA)

6681 OD An accurate modeling, simulation, and analysis tool for predicting and estimating Raman LIDAR system performance [6681-16]

R. J. Grasso, L. P. Russo, J. L. Barrett, J. E. Odhner, P. I. Egbert, BAE Systems (USA)

6681 DE Backscatter properties of hygroscopic aerosols using models, combined multiwavelength Raman lidar, GPS, and radiosonds [6681-17]

D.-V. Vladutescu, City College, CUNY (USA) and Graduate Ctr., CUNY (USA); B. Gross,

Y. Wu, City College, CUNY (USA); L. Charles, City College, CUNY (USA) and Graduate Ctr., CUNY (USA); F. Moshary, S. Ahmed, City College, CUNY (USA)

\section{SPACE-BORNE LIDAR}

6681 OF Development of a validated end-to-end model for space-based lidar systems (Invited Paper) [6681-18]

M. Lieber, C. Weimer, M. Stephens, R. Demara, Ball Aerospace \& Technologies Corp. (USA)

6681 OG Modeling spaceborne lidar returns from vegetation canopies [6681-20]

B. Hu, York Univ. (Canada); I. Tcherniavski, A. Dudelzak, A. Koujelev, Canadian Space

Agency (Canada)

\section{DIFFERENTIAL ABSORPTION LIDAR}

$6681 \mathrm{OH}$ Development of a wavelength stabilized seed laser system for an airborne water vapour lidar experiment (Invited Paper) [6681-22]

H. Schwarzer, A. Börner, A. Fix, B. Günther, H.-W. Hübers, M. Raugust, F. Schrandt, M. Wirth, German Aerospace Ctr. (Germany)

6681 ol Initial results from a water vapor differential absorption lidar (DIAL) using a widely tunable amplified diode laser source [6681-23]

M. D. Obland, Montana State Univ. (USA) and NASA Langley Research Ctr. (USA);

A. R. Nehrir, K. S. Repasky, J. A. Shaw, J. L. Carlsten, Montana State Univ. (USA)

6681 0J Man-made structures influence on ozone behavior revealed by LIDAR [6681-24]

J. Moreno, C. Laborda, S. Moreno-Grau, A. Garcia-Sánchez, N. Vergara-Juarez,

B. Elvira-Rendueles, M. J. Martinez-Garcia, J. Moreno-Clavel, Polytechnic Univ. of

Cartagena (Spain) 


\section{AEROSOL AND CLOUD MEASUREMENTS II}

6681 OK Atmospheric transport of smoke and dust particulates and their interaction with the Planetary Boundary Layer as observed by multi-wavelength lidar and supporting instrumentation [6681-25]

L. Charles, Optical Remote Sensing Lab., CCNY (USA) and CUNY Graduate Ctr. (USA);

B. Gross, Y. Wu, Optical Remote Sensing Lab., CCNY (USA); V. Vladutescu, Optical Remote Sensing Lab., CCNY (USA) and CUNY Graduate Ctr. (USA); F. Moshary, S. Ahmed, Optical Remote Sensing Lab., CCNY (USA)

6681 OL Novel applications of an affordable short-range digital LIDAR [6681-26] M. Allard, F. Cayer, Y. Champagne, F. Babin, D. Cantin, INO (Canada)

6681 ON Measurements of PM10 profiles in ABL with lidar and DA-OPC at Beijing [6681-28]

H. Hu, Anhui Institute of Optics and Fine Mechanics (China)

668100 De-noising LiDAR signal using wavelet technique [6681-29]

V. Sivakumar, Council for Scientific and Industrial Research (South Africa)

POSTER SESSION

6681 OR Development of single-frequency laser for direct-detection wind lidar [6681-14]

J. Zhou, H. Zang, T. YU, J. Liu, W. Chen, Shanghai Institute of Optics and Fine Mechanics (China)

6681 OS Remote location of the effects of SHF radiation on the stratosphere via radiation of atomic hydrogen at $1420 \mathrm{MHz}$ [6681-32]

G. A. Kolotkov, S. T. Penin, Institute of Atmospheric Optics (Russia)

6681 OT Raman-Mie lidar measurements of low and optically thin cloud [6681-33]

Y. Wu, S. Chaw, B. Gross, V. Vladutescu, L. Charles, N. Cao, F. Moshary, S. Ahmed, City College, CUNY (USA)

6681 OU The relationships between the zonal temperature variation and ozone distribution in the Northern Hemisphere winter stratosphere [6681-34]

C. Shi, Nanjing Univ. of Information Science \& Technology (China); B. Zheng, Guangzhou Institute of Tropical and Marine Meteorology (China); S. Zhong, Nanjing Univ. Of Information Science \& Technology (China)

6681 OV Automation of a lidar for high-speed internet operation [6681-36]

E. Landulfo, N. D. Vieira, Jr., G. E. C. Nogueira, A. M. Carrilo, J. T. Vidal, Instituto de Pesquisas Energéticas e Nucleares (Brazil)

6681 0X Rayleigh LiDAR investigation of stratospheric sudden warming over a low latitude station, Gadanki (13.5 ${ }^{\circ}$; $79.2^{\circ}$ E): a statistical study [6681-41]

D. V. Charyulu, Lab. de l'Atmosphère et des Cyclones, CNRS, Univ. de La Réunion (France) and National Atmosphere Research Lab. (India); V. Sivakumar, Council for Scientific and Industrial Research (South Africa); H. Bencherif, Lab. de l'Atmosphère et des Cyclones, CNRS, Univ. de La Réunion (France); D. N. Rao, National Atmospheric Research Lab. (India) 
$66810 Z$ High-reliability pump module for non-planar ring oscillator laser [6681-43]

D. T. Liu, Y. Qiu, D. W. Wilson, S. Dubovitsky, S. Forouhar, Jet Propulsion Lab. (USA)

668110 Lensless methods to transform small angular displacement of a laser beam into circular scanning and to receive radiation by the small-sized device within the limits of a spatial hemisphere [6681-39]

Y. Polkanov, B.I. Stepanov Institute of Physics (Belarus)

668111 Sounding of the environment by means of the un-impulse of the low-power continuous source [6681-38]

Y. Polkanov, B.I. Stepanov Institute of Physics (Belarus)

Author Index 


\title{
Conference Committee
}

\author{
Conference Chair \\ Upendra N. Singh, NASA Langley Research Center (USA) \\ Program Committee \\ Kazuhiro Asai, Tohoku Institute of Technology (Japan) \\ Andreas Behrendt, Universität Hohenheim (Germany) \\ Edwin W. Eloranta, University of Wisconsin, Madison (USA) \\ Tetsuo Fukuchi, Central Research Institute of Electric Power Industry \\ (Japan) \\ Bruce M. Gentry, NASA Goddard Space Flight Center (USA) \\ Robert M. Hardesty, National Oceanic and Atmospheric \\ Administration (USA) \\ Floyd E. Hovis, Fibertek, Inc. (USA) \\ Syed Ismail, NASA Langley Research Center (USA) \\ Toshikazu Itabe, National Institute of Information and Communications \\ Technology (Japan) \\ Gary W. Kamerman, FastMetrix, Inc. (USA) \\ Philippe L. Keckhut, Service d'aeronomie (France) \\ Kohei Mizutani, National Institute of Information and Communications \\ Technology (Japan) \\ D. Narayana Rao, National Atmospheric Research Laboratory (India) \\ Shiv K. Sharma, University of Hawaii at Manoa (USA) \\ Randhir K. Sinha, LS College (India) \\ William R. Stabnow, NASA Headquarters (USA) \\ David M. Tratt, The Aerospace Corporation (USA) \\ Jinxue Wang, Raytheon Santa Barbara Remote Sensing (USA) \\ Jirong Yu, NASA Langley Research Center (USA) \\ Jun Zhou, Anhui Institute of Optics and Fine Mechanics (China)
}

Session Chairs

Aerosol and Cloud Measurements I

Upendra N. Singh, NASA Langley Research Center (USA)

William R. Stabnow, NASA Headquarters (USA)

Wind Lidar I

Bruce M. Gentry, NASA Goddard Space Flight Center (USA)

Jinxue Wang, Raytheon Santa Barbara Remote Sensing (USA) 
Wind Lidar II

Bruce M. Gentry, NASA Goddard Space Flight Center (USA)

Jinxue Wang, Raytheon Santa Barbara Remote Sensing (USA)

Raman Lidar

Eduardo Landulfo, Instituto de Pesquisas Energéticas e Nucleares (Brazil)

Space-Borne Lidar

Jirong Yu, NASA Langley Research Center (USA)

Michael J. Kavaya, NASA Langley Research Center (USA)

Differential Absorption Lidar

Scott M. Spuler, National Center for Atmospheric Research (USA)

Shiv K. Sharma, University of Hawaii at Manoa (USA)

Aerosol and Cloud Measurements II

Jun Zhou, Anhui Institute of Optics and Fine Mechanics (China)

Huanling Hu, Anhui Institute of Optics and Fine Mechanics (China) 